\title{
Composition and constitution of pyrrhotite concentrate pellets after partial oxidative roasting
}

\author{
(C) Alexander M. Klyushnikov, ${ }^{+}$and Evgeny N. Selivanov* \\ Laboratory of Non-Ferrous Metals Pyrometallurgy. Institute of Metallurgy of the Ural Branch of the Russian \\ Academy of Sciences. Amundsen St., 101. Yekaterinburg, 620016. Russia. \\ Phone:+7 (343) 382-21-18.E-mail:amk8@mail.ru
}

*Supervising author; ${ }^{+}$Corresponding author

Keywords: pyrrhotite concentrate, pellets, roasting, nickel, phases, structure, microtexture.

\section{Abstract}

Using the methods of X-ray powder diffraction, electron microscopy and energy dispersive spectral microanalysis, the material composition of the pyrrhotite concentrate pellets subjected to partial oxidative roasting was studied. The structure and elemental composition of the obtained products are estimated, the features of the interphase distribution of elements are revealed. Heat treatment $\left(800{ }^{\circ} \mathrm{C}\right)$ of the concentrate in an oxidizing atmosphere leads to a partial change in the forms of the basic elements. The proposed sequence of high-temperature reactions of solid phases and oxygen is established. The effect of oxidation on the formation of the zoning of the granules was confirmed. The zoning is associated with various desulfurization levels, which decreasing from $81 \%$ in the surface layer to $46 \%$ in the core.

With deepening, the aleuritic structure of the material acquires the characteristics of an aleuropsammitic structure, the microtexture retains a random porous character, and the pore size is reduced from 38 to $10 \mu \mathrm{m}$. The clastic component, represented by grains (size up to $145 \mu \mathrm{m}$ ) of a comminuted, angular, and semirounded shape, corresponding in composition to the $\mathrm{Fe}_{1-\mathrm{x}} \mathrm{S}-\mathrm{FeO}_{\mathrm{m}}$ and $\mathrm{FeS}_{2}-\mathrm{FeO}_{\mathrm{m}}$ systems, as well as $\mathrm{CaSO}_{4}$, spinelids and silicates, is supplemented by $\mathrm{CuSO}_{4}$ and $(\mathrm{Fe}, \mathrm{Ni})_{9} \mathrm{~S}_{8}$ crystals. Basal cement (size up to $25 \mu \mathrm{m}$ ), similar in mineral composition to debris, passes into the pore cement $(15 \mu \mathrm{m})$, marked by the predominance of complex aluminosilicates, calcium sulfates and sulfides, its volume fraction is reduced from 88 to $45 \%$. Nickel in all layers of granules is associated with iron oxides and sulfides, which are part of the clastic and cement components, its highest contents (6.1-7.6 \% wt.) are confined to $\mathrm{Fe}_{2} \mathrm{O}_{3}$ and $(\mathrm{Fe}, \mathrm{Ni})_{9} \mathrm{~S}_{8}$. In detrital grains of $\mathrm{CuSO}_{4}$, up to $4.9 \%$ wt. $\mathrm{Cu}$ was found. The close contact of higher iron oxides and sulfides contributes to the fact that the enrichment of oxide phases with nickel occurs during the oxidation period. The porous nature of the microtexture of the granules weakens the intra-diffusion difficulties of the oxidation process and contributes to the completeness of the transformation of sulfides into oxides.

Subsequent smelting of a partially oxidized compacted concentrate with a flux (silicate nickeliferous ore) will make it possible to gain a matte with a regulated non-ferrous metal content.

\section{References}

[1] F.K. Crundwell et al. Extractive metallurgy of nickel, cobalt and platinum-group metals. Oxford: Elsevier. 2011. 610p.

[2] A.V. Vanyukov, V.P. Bystrov, A.D. Vaskevich. Smelting in a liquid bath. Moscow: Metallurgy. 1988. 208p. (russian)

[3] I.D. Reznik, G.P. Ermakov, Ya.M. Shneerson. Nickel. Vol.3. Moscow: Science and technology. 2003. 608p. (russian)

[4] Information and technical guide to the best available technologies 12-2016. Production of nickel and cobalt. Moscow: Bureau of the best available technologies. 2016. 194p. (russian)

[5] V.E. Lotosh, A.I. Okunev. Flameless agglomeration of ores and concentrates. Moscow: Science. 1980. 217p. (russian)

[6] A.A. Galnbek, I.N. Beloglazov, V.O. Golubev, E.V. Kalyukina. Electric smelting of briquetted sulfide copper-nickel raw materials. St. Petersburg: "Ore and metals» Publishing House. 2002. 90p. (russian)

[7] L.Sh. Tsemekhman, V.B. Fomichev, L.N. Yertseva et al. Atlas of mineralogical raw materials, technological products, and commercial products of the Polar Branch of the MMC «Norilsk Nickel» OJSC. Moscow: "Ore and Metals» Publishing House. 2010. 336p. (russian) 
[8] G.V. Skopov. Oxidation kinetics of sulfide copper-containing pellets. Izvestiya Vysshikh Uchebnykh Zavedenij. Tsvetnaya Metallurgiya. 2018. No.8. P.13-20. DOI: dx.doi.org/10.17073/0021-3438-2018-213-20. (russian)

[9] G.V. Skopov, V.A. Perepelitsyn. On the spatial separation of copper and iron compounds during the oxidation of sulfide pellets. Izvestiya Vysshikh Uchebnykh Zavedenij. Tsvetnaya Metallurgiya. 1991. No.4. P.31-37. (russian)

[10] Huifang $\mathrm{Xu}$, Seungyeol Lee, and Hongwu Xu. Luogufengite: A new nano-mineral of $\mathrm{Fe}_{2} \mathrm{O}_{3}$ polymorph with giant coercive field. American Mineralogist. 2017. Vol.102. P.711-719.

[11] A.M. Klyushnikov, and E.N. Selivanov. Thermodynamic modeling of the joint processing of oxidized nickel ores and sulfide copper-bearing ores. Butlerov Communications. 2017. Vol.49. No.1. P.34-42. DOI: $10.37952 /$ ROI-jbc-01/17-49-1-34

[12] V.A. Zharikov. Fundamentals of physical geochemistry. Moscow: Publishing House of the Moscow University: Science. 2005. 556p. (russian)

[13] E.N. Selivanov, A.M. Klyushnikov, and R.I. Gulyaeva. Application of sulfide copper ores oxidative roasting products as a sulfidizer when melting nickeliferous ores to matte. Metallurg. 2019. No.8. P.8390. (russian)

[14] A.M. Klyushnikov, and E.N. Selivanov. Simulation of the joint processing of pyrrhotite concentrate and nickeliferous oxidized ore. Butlerov Communications. 2019. Vol.58. No.5. P.110-117. DOI: 10.37952/ROI-jbc-01/19-58-5-110

[15] Dawei Yu, and Torstein A. Utigard. TG/DTA study on the oxidation of nickel concentrate. Thermochimica Acta. 2012. No.533. P.56-65.

[16] A.V. Vanyukov, N.I. Utkin. Complex processing of copper and nickel raw materials. Chelyabinsk: Metallurgy. 1988. 432p. (russian)

[17] D. Vaughan, J. Craig. Chemistry of sulfide minerals: transl. from English. Moscow: World. 1981. 567p. (russian)

[18] A. Roine. HSC Chemistry, Version 6.12 for Windows, Outotec Research Oy. Pori, Finland, 1974-2007.

[19] Dawei Yu, Torstein A. Utigard, and Mansoor Barati. Fluidized Bed Selective Oxidation-Sulfation Roasting of Nickel Sulfide Concentrate: Part I. Oxidation Roasting. Metallurgical and Materials Transactions B. 2013. Vol.45(2). P.653-661. DOI: 10.1007/s11663-013-9958-x.

[20] Dawei Yu, Torstein A. Utigard, and Mansoor Barati. Fluidized Bed Selective Oxidation-Sulfation Roasting of Nickel Sulfide Concentrate: Part II. Sulfation Roasting. Metallurgical and Materials Transactions B. 2014. Vol.45. Iss.2. P.662-674. DOI: 10.1007/s11663-013-9959-9.

[21] A.G. Khoroshavin. Forsterite. Moscow: Heat Engineer. 2004. 368p. (russian)

[22] I.D. Reznik, G.P. Ermakov, and Ya.M. Shneerson. Nickel. Vol.2. Moscow: Science and Technology. 2001. 468p. (russian)

[23] Yu.A. Savinova, A.B. Portov, L.Sh. Tsemekhman. Investigation of influence of roasting parameters of sulfide copper-nickel concentrate on material composition of obtained cinder. Tsvetnye Metally. 2014. No.6. P.23-28. (russian)

[24] E.N. Selivanov, A.M. Klyushnikov, V.M. Chumarev, R.I. Gulyaeva, and V.G. Lobanov. Composition and structure of products of the joint smelting of oxidized nickel ores and sulfide copper ores. Butlerov Communications. 2016. Vol.47. No.7. P.36-42. DOI: 10.37952/ROI-jbc-01/16-47-7-36 